\title{
Public funded heritage rejuvenation mechanism in Georgetown, Penang
}

\author{
Y. Rahman, Q. Norhisham, F. R. Razali \& S. S. Zubir \\ Center of Studies for Architecture, Faculty of Architecture, \\ Planning and Surveying, Universiti Teknologi MARA, Malaysia
}

\begin{abstract}
On July 7, 2008, Georgetown was formally inscribed as a UNESCO World Heritage Site. It was recognized for its unique heritage of a living multicultural community. Since then there have been various conservation projects within the vicinity of Georgetown, but the initiative seems to be fighting a losing battle. There have been a few major significant conservation projects developed especially in the cultural enclave in order to maintain the status-quo of a world heritage site. Engaging Love Lane as a pilot project to experiment on a new mechanism of heritage rejuvenation involving public participation and extensive use of technological infrastructure could be an alternative approach in conservation development. Heritage value in Love Lane will be enhanced with the use of information technology via the 'Groupon' method which has been proven successful among online shoppers. It is about time this method of collective fund is put to the test in conservation and management of heritage sites. This theoretical urban design exercise covers a 12-acre block of old shophouses in restoring appropriate historical artifacts through smart partnership among stakeholders. If the project is a success, it could be the key to safeguarding not only Penang, but hundreds of world heritage sites facing similar problems.
\end{abstract}

Keywords: UNESCO World Heritage Site, Love Lane, public participation, public funded conservation mechanism, Penang heritage shop-houses.

\section{Introduction: Love Lane history}

George Town, Penang has always been a port city even since its inception during the rule of the Malay Sultanate. The strategic location of this Island in the 
Malacca Strait drew the attention of the British to acquire the island for military purposes [1]. But soon after they realized that the island is not fully fit for such military installations but gradually transformed itself into a trading center instead. Here in the new and thriving port, travellers around the world that pass by the Malacca Straits would stop on the island to rest, refill resources and participate in trade. This flock of foreign sailors from around the world resulted in a multi racial community which existed in the midst of the city's population.

Weary travellers come to the island to rest and enjoy themselves for a brief amount of time before they set sail at sea again. It is said that these travellers will stay along Love Lane and would be entertained by young girls and accompanied throughout their stay. The Chinese believe that this is the reason as to how Love Lane got its name, as it was the first site for early 19th century brothels to flourish. The adjacent road, Muntri Street, was where the rich Straits Chinese housed their mistresses. There is another belief that it was named after a British officer named Love, but this has not been verified. Then there is the somewhat farfetched theory that Love Lane was named after the self-flagellation procession staged by Shiite Muslims who in the early 19th century, paraded from the Indian Muslim settlements in Chulia Street through Love Lane, on their way to the sea, while performing the painful rituals of flogging themselves, in remembrance of Ali, the son-in-law of the Prophet Muhammad [2].

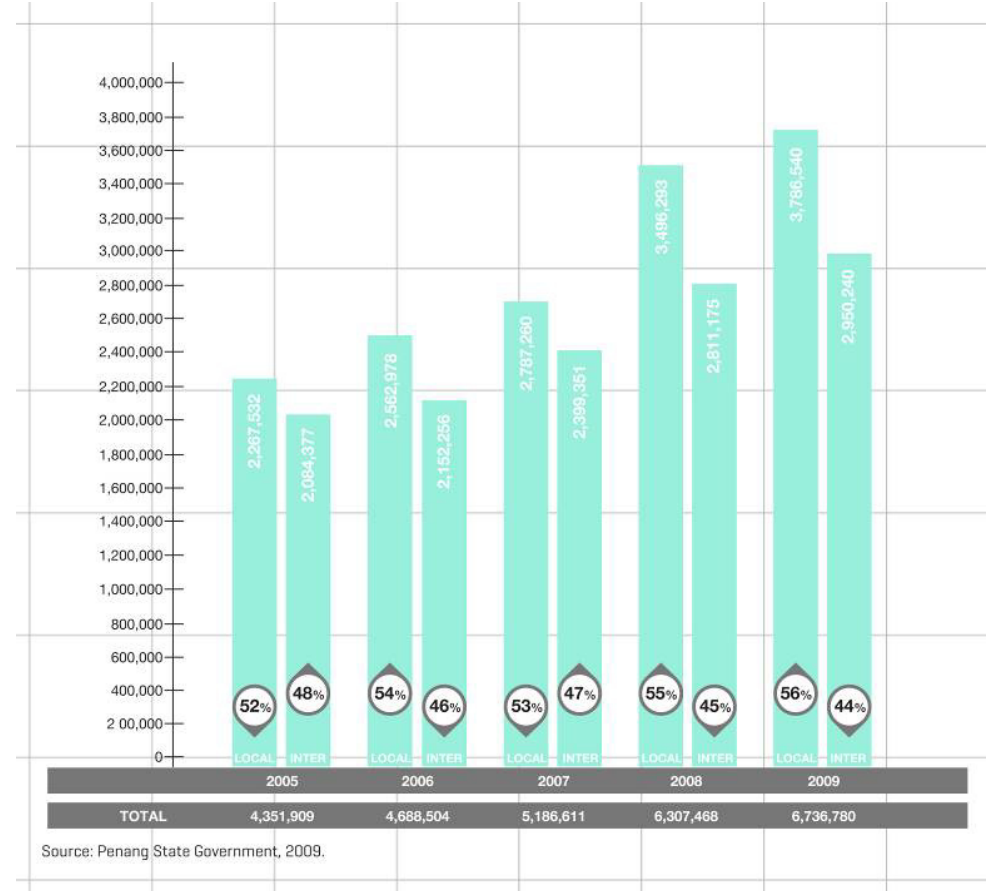

Figure 1: Graph analysis of local and foreign tourists in Penang between 2005 and 2009 [5]. 
The history of Love Lane is diverse and these three main sources quote the establishment of Love Lane, but no complete agreement has ever been made. Despite the debate, Love Lane has indeed been a traveller's transit for over 200 years and today it still continues its identical role [3]. The intention of the project is to preserve the original site function as a travellers' heart within a contemporary context (Figure 1). This rejuvenation of the site's native function as a temporary accommodation area for travellers will once again bring the vibrancy of racial and cultural diversity that once enlivened the festivals in Love Lane, Georgetown's Heritage City Site.

\section{Dilemmas and potentials}

The heritage shop-houses are one of Penang's most unique treasures. Unfortunately the condition of the shop lots is deteriorating and both Penangites and tourists are unable to appreciate the full potential that these treasures have to offer. During the early years, back lanes of these shop-houses were a mere network for sewerage disposal left in buckets to be collected from these alleys [4]. Today, these areas become wasted urban voids as neither vehicles nor pedestrians are seen along these back lanes. The potential of exploring back lanes as a new network dedicated solely for pedestrians where various public spaces will merge with the shop-houses and their courtyards will further enliven the city. The potential of a new typology of urban fabric is seen without depriving the shop lots of their heritage value. Instead, tourists and locals are able to experience new exciting spaces of the shop-houses that open up to beautiful pedestrianized back lanes.

\section{Hypothesis}

The Love Lane Pilot Project is an experimental attempt of heritage restoration using a social mechanism. The inner working of the project is heavily dependent upon technology and internet infrastructure that was not possible 10 years ago. By harnessing the power of communication through the internet, the project would be able to reach more people in a wider age range to participate in this restoration effort. As a public experiment, the key tool for everyone interested for the betterment of this project will be a website, with a simple interface that will show the options, planning and development of the project on a real time plan (Figure 2). If enough shares are sold, the project will commence immediately. Since conservation costs are high, shop lot owners as well as the

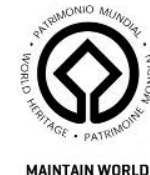

MAINTAIN WORLD
HERITAGE STATUS
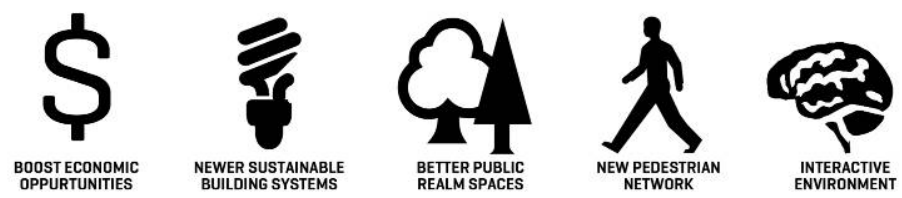

Figure 2: $\quad$ Strategies that will be the spine action course for the conservation effort. 
general public does not actually have a large sum of money to conduct a conservation project individually. Only by parcellation of project cost, can people invest by buying smaller parcels of shares of the conservation project.

\section{User}

In order to ensure a successful outcome, the conservation mechanism will be played by three parties. These key players play an important role in the restoration effort of the heritage enclave. These players are the subscriber, expert and host (Figure 3).
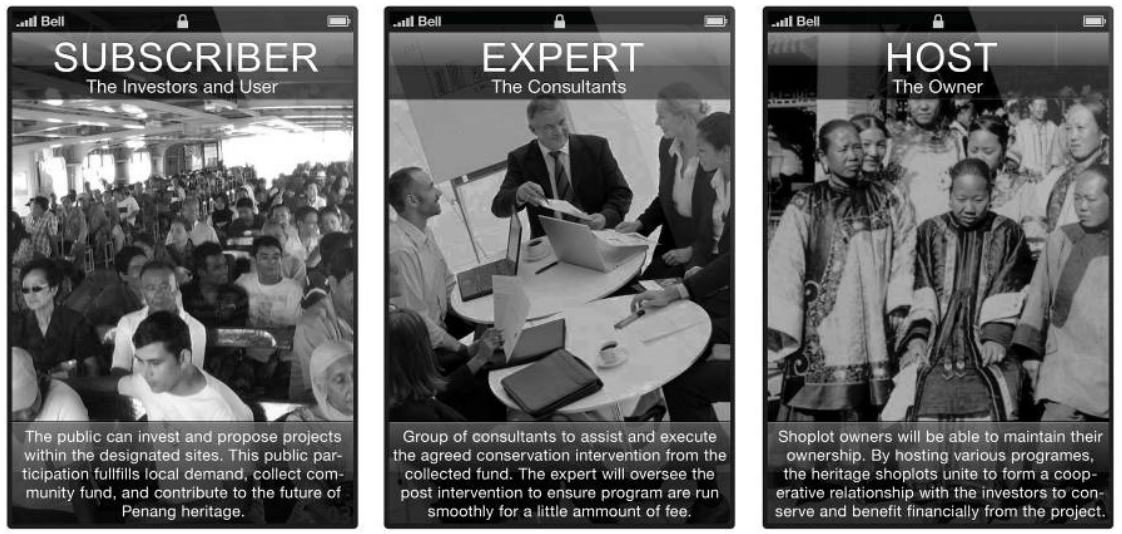

Figure 3: Key players of the conservation mechanism.

\subsection{Subscriber: the investors and users}

The public can invest and propose projects within the designated site. This public participation fulfils local demand, collects community fund, and contributes to the future of Penang heritage. The public will develop the selected site for the experiment. It can be public or private and his/her suggestion will lay the foundations of the new project so that the project will not be made solely by theoretical decisions. The public becomes the dominator as they can invest and propose projects within the designated site. This public participation allows new generations to contribute to the future of Penang heritage.

\subsection{Expert: the consultants}

A group of consultants will assist and execute the agreed conservation intervention from the collected fund. The expert will supervise the post intervention procedures to ensure the programs are run smoothly. The collaborator with preservation and sustainable knowledge will be the one that suggests specific solutions, taking into account the feasibilities studies made after the public proposes a designated program. 


\subsection{Host: the owner}

Shop lot owners will be able to maintain their ownership of their property. They can propose a vision for their property before investment blocks are put up for sale. When their property is successfully operational, they can choose to run the business or set up a representative managing body. By hosting various programs, the heritage shop lots unite to form a cooperative relationship with the investors to conserve and benefit financially from the project.

\section{Strategy: public funded conservation mechanism}

Conservation efforts of the heritage built form in Penang run by the NGOs and charismatic individuals are slow and inefficient, mainly due to funding difficulties. The new mechanism of conservation will involve the public as one of the main shareholder. The mechanism draws fund from the general public which includes development for economical regeneration and social sustainability (Figure 4).

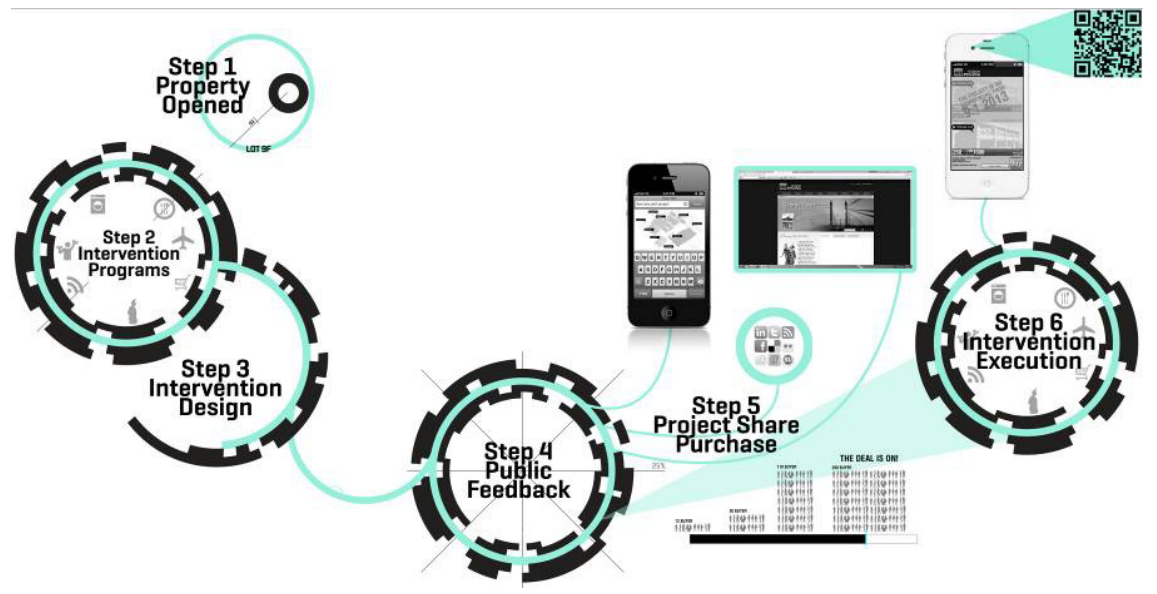

Figure 4: $\quad$ Flow chart of the public funded conservation mechanism.

The Love Lane Pilot Project (LLPP) Committee will conduct and run the development under the blessing of the Penang's State Government. General description on how the mechanism will work is fairly similar to the Groupon [6] online shopping experience. Certain deals will be posted online and if the product attracts enough buyers, the product will be sold with the discounted price. The adaptation made for this mechanism is, instead of product, it will be a heritage development project and if the proposal attracts enough investors, the project will commence. The mechanism's operation will follow the action flow as described in Figure 5. 


\subsection{Step 1: opening up the property}

The intention to open the property for investment will come from the owner. As the owner realises the economic potential of his property, he refers to the LLPP committee to device a proper and suitable proposal.

Host: $\quad$ Signing letter of agreement to open property with the LLPP.

Subscriber: None.

Expert: $\quad$ Evaluate property market value and the feasibility studies.

LLPP: Upload project to the website and start the promotion of the project.

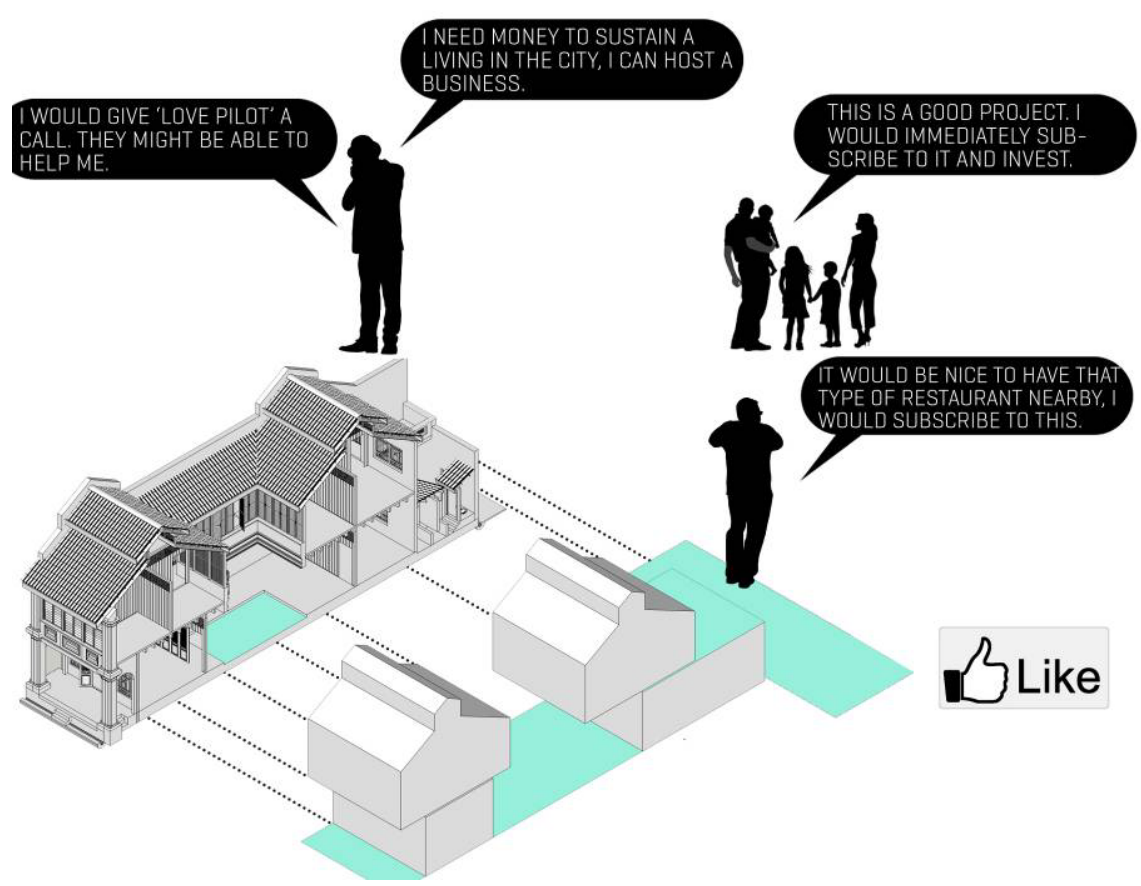

Figure 5: $\quad$ Example of program insertion proposal for conservation purposes. The project will bring a lot of interest to the public and investors alike.

\subsection{Step 2: programs}

The owner will/can propose a vision for the development of his property. The public can contribute to the blueprint of the development with vital information such as preference, market demand and context suitability through polls and surveys.

Host: $\quad$ Provide vision for the development.

Subscriber: Answer surveys, polls and give suggestions for the development. 
Expert: $\quad$ Provide development guidelines and proposals.

LLPP: Conduct polls and surveys online and gather assessment information for the development brief.

\subsection{Step 3: investment}

The proposal's research conducted by LLPP will eventually produce a design brief. A competent design team will be selected to redesign, provide a conservation and business plan for the new enterprise. The proposal will be uploaded on the internet along with other additional information. The project cost will be divided into smaller investment blocks.

Example: A RM 200,000 hostel conversion project will be divided into 100 investment blocks of RM 2000 each.

These investment blocks can be purchased online by the public via the website. If all investment blocks are sold, the construction of the project will commence.

Host: $\quad$ None

Subscriber: Purchase investment block if they are interested in the proposal. Expert: $\quad$ Prepare design proposal, business plan and advertising strategies. LLPP: Moderate and regulate fund, legalise investment block ownership and apply development order from the State government.

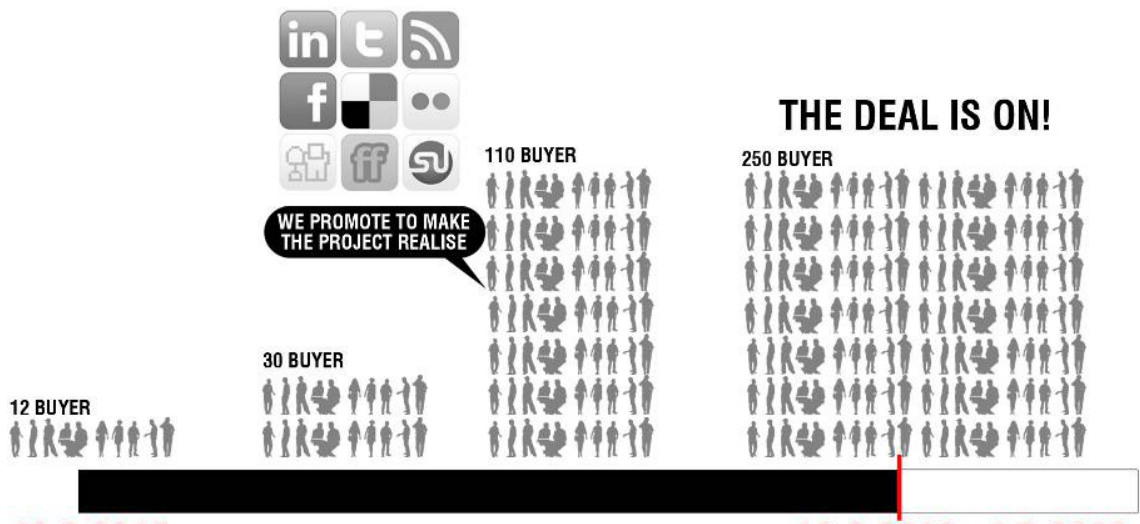

12.9 .2012

Figure 6: Scenario diagram illustrating the relationship between volume of investment block sold against project realization.

\subsection{Step 4: intervention}

After development permits have been obtained, the construction and conservation efforts will commence through surveillance of the conservation 
architect. He will supervise the construction to ensure heritage values will not be undermined by modern construction methods.

Host: $\quad$ Run the business or set up a representative managing body.

Subscriber: Gain profit based on their volume of investment blocks.

Expert: Give business consultation and preservation guidelines.

LLPP: $\quad$ Promote the new conservation effort in the mass media.

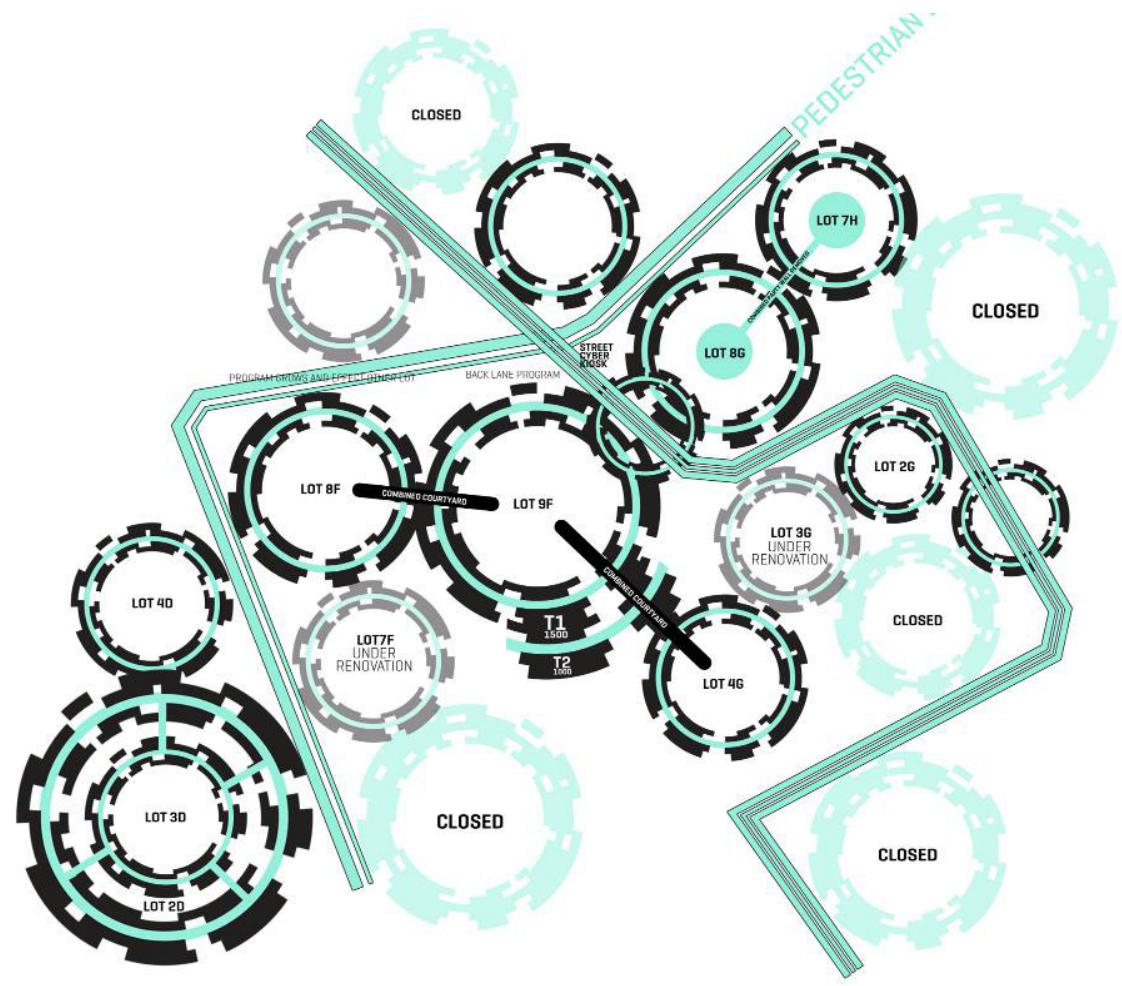

Figure 7: $\quad$ Property status of the Love Lane enclave, intervention linkages and association diagrams.

\section{Program intervention: the public realm}

The project can be easily divided into three main components. The secondary network consists of street and lane, the heritage shop lots and the Love Square (Figure 8). These components are inter-related in the urban structure and programming effort will become the glue for the three entities to combine spatially. 


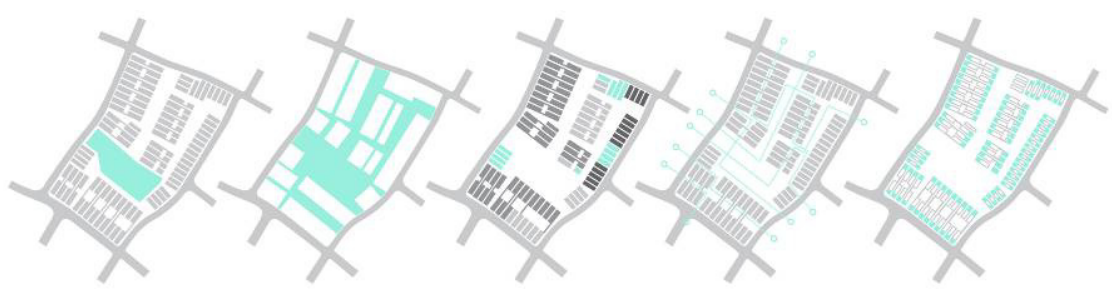

Figure 8: Index diagrams of the Love Lane urban blocks, inner streets, pedestrian access and courtyards.

\subsection{Secondary network: street and lane programming}

The back lanes of the shop lots once became the services route of sanitation and garbage service collection [7]. As modern systems of sanitation and garbage collection emerged, the role of the back lanes has faded away. In Love Lane Pilot Project, the back lane of the inner urban block will be transformed as the main pedestrian connection. Previously, they were seen as a liability and a separator of building rows [8]. We on the other hand see it as a binding layer of rows to form a city block as a whole. As a result, all rows have multiple frontage exposure to both vehicular and pedestrian networks. The back lanes also act as safe car-free corridors which are disabled-friendly and child-friendly due to the absence of road curbs and vehicles. These transform the dynamics of social interaction that happen in the perimeter of the urban block into a more congregated inner block of social interaction among users (Figure 9).

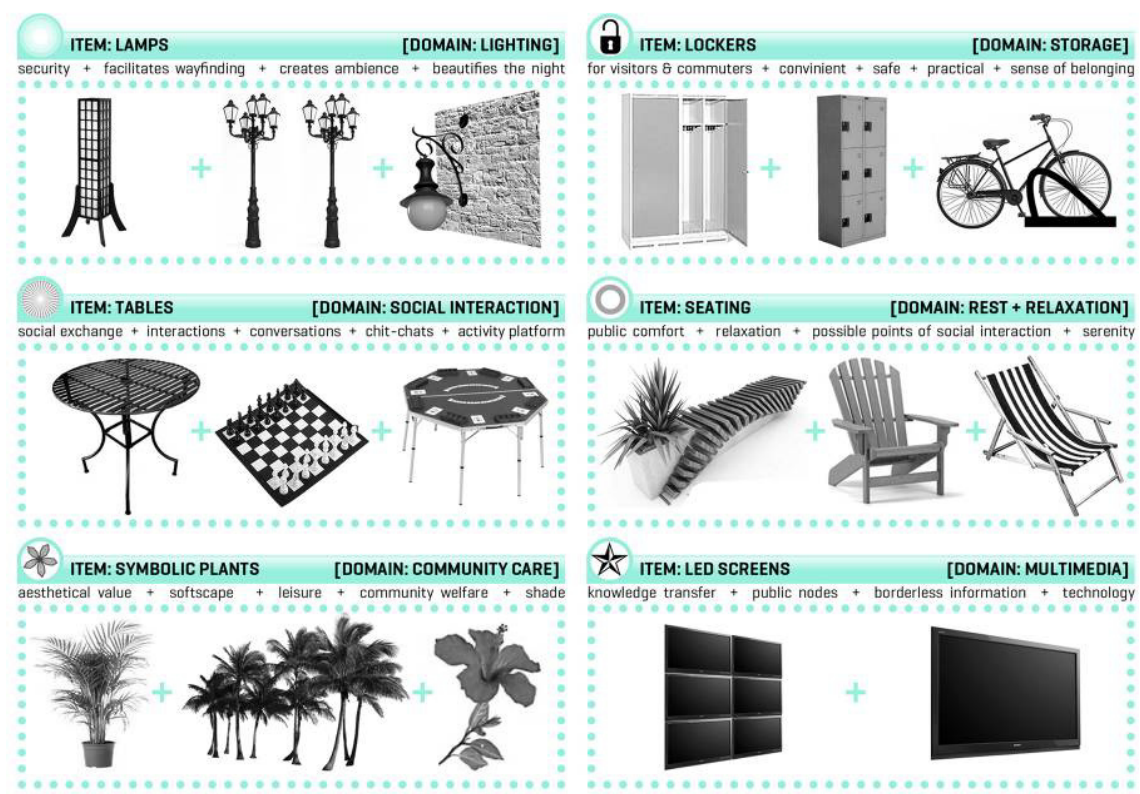

Figure 9: Distribution programs that filled the streetscape of inner street. 


\subsection{Regeneration: heritage shop lots}

The existing typology of shop lot design in the vicinity of Georgetown usually features an inner courtyard (Figure 10). These courtyards play an important role to ventilate, and provide enough natural lighting into the shop lot [9]. This unique feature of spatial quality poses a very flexible spatial planning that can be converted into contemporary programs such as hostels, boutiques, restaurants and various others, contributing to the formation of international transit nodes (Figure 11).

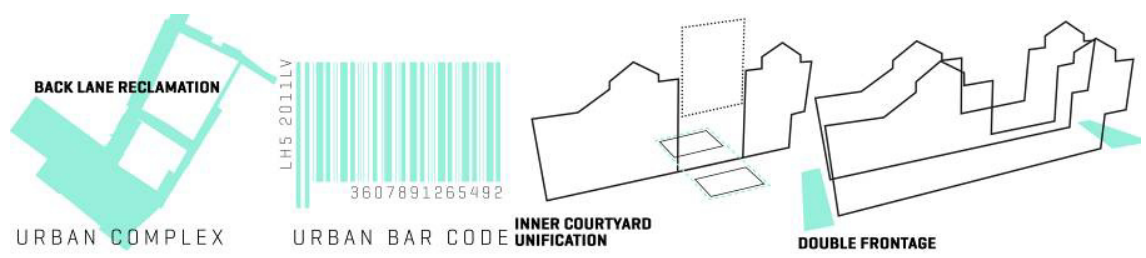

Figure 10: Physical urban intervention and new spatial strategies for shop lots.

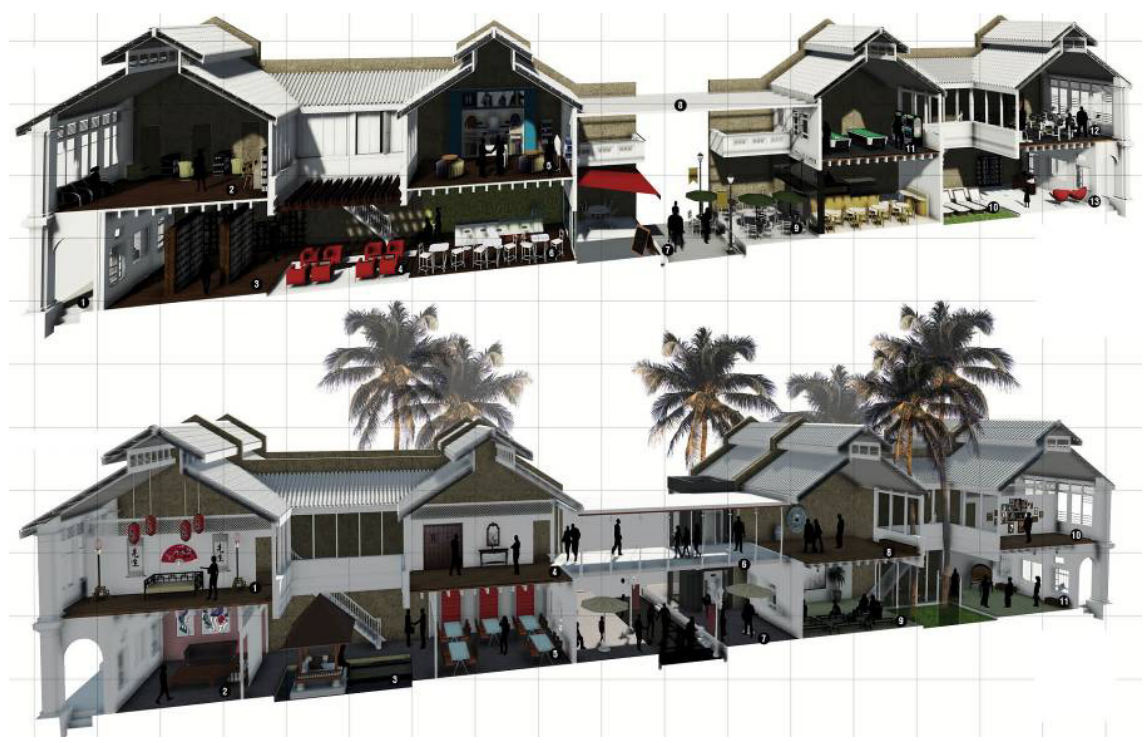

Figure 11: Regeneration proposal that explores the spatial dynamics of the shop lot, the inner courtyard, the back lane and the second storey connections. 


\subsection{Public plaza: Love Square}

The square becomes the main public open space in the heritage enclave of George Town. It not only hosts a vast variety of public activities, but acts as the primary urban green lung. Its pavement consists of 6 different materials that breathe and cleanses the city's harmful residue. A sub basement car park is
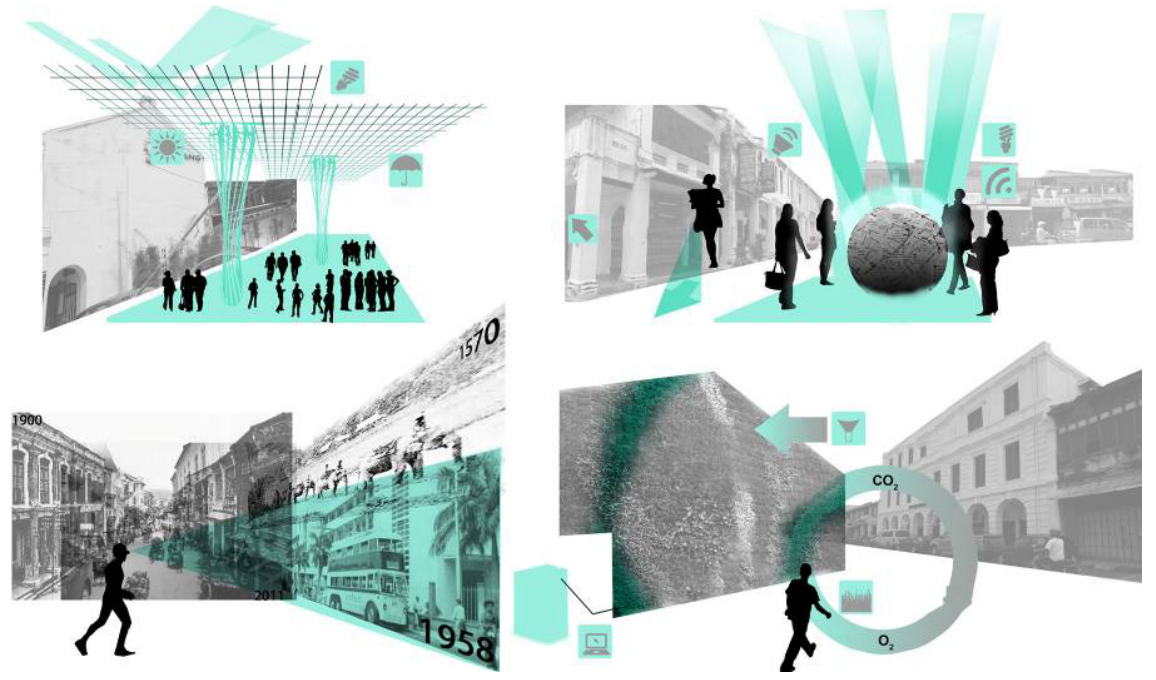

Figure 12: Collection of street installations that interact with the visitor.

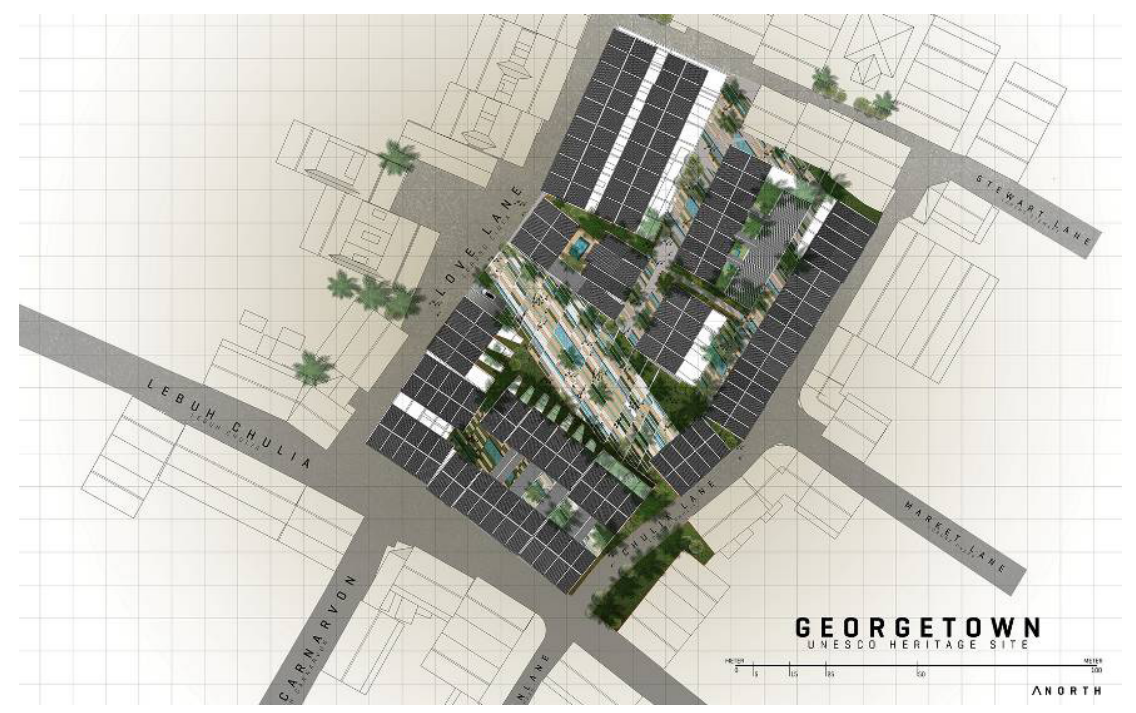

Figure 13: Overall master plan of the Love Lane regeneration mechanism. 
dedicated for hostel visitors and transportation vehicles for tourist is placed under the square. This ensures a steady flow of public circulation both in and out of the site with taxis, chartered vans and rented vehicles.

The square serves as the main activity hub for international travellers to relax, interact and appreciate the cultural enclave of George Town. The square continues to penetrate the back lanes and inner streets with a similar diagonalgrid pattern.

\section{Conclusion}

The Groupon method has proven itself successful among online shoppers. It is about time this method of collective fund is put to the test in property investments and development. As the next generation comes in, it signifies less importance on heritage as the previous generation did. But with a factor of investment, in a fun and easy way, the customers stick around. Our precious Penang heritage can now be saved by the continuous public support.

This project however is proposed as an experiment on a mere 12 acre block. If the project succeeds and expands, this public funded conservation mechanism could be the key to save not only Penang, but hundreds of other world heritage sites facing the same problem of extinction. By regaining an international crowd, imagine how well decaying historic cities can revitalize by a simple initiative of Love.

\section{References}

[1] Kohl, D.G., Chinese Architecture in the Straits Settlements and West Malaysia: Temples, Kongsis and Houses, Kuala Lumpur: Heinemann Asia, 1984.

[2] Love Lane, George Town, retrieved from http://www.penangtraveltips.com/love-lane.htm, 19/01/2013.

[3] Innovation Zone (M) Sdn. Bhd., Penang Tourism Calendar of Events 2011/12 [Brochure], June 2011.

[4] Melaka and George Town Historic Cities of the Straits of Malacca [Brochure], George Town World Heritage Inc, 2010.

[5] Penang State Government, Analysis of local and foreign tourists in Penang between 2005 and 2009, Official Report, 2009.

[6] Groupon Inc., How It Works, retrieved from www.groupon.com, 15/01/2013.

[7] Zubir, S.S. and Sulaiman, W.A., 'Deciphering urban cultural heritage, community and the city', in Marchettini, N., Brebbia, C. A., Tiezzi, E. and Wadhwa, L.C., The Sustainable City III, Southampton: WIT Press, 2004.

[8] Tan Yeow Wooi, 'Heritage Shophouse Features' [Illustration], Melaka and George Town Historic Cities of the Straits of Malacca, Arts-Ed GTWHI, 2003.

[9] Arts_Ed and Re-cap, George Town Architectural Walkabout [Brochure], CIMB Foundation, 2011. 